\title{
WICK SKINNER: A LIFE SAILING AGAINST THE WIND
}

\author{
ROBERT H. HAYES
}

Harvard Business School, Boston, Massachusetts 02163, USA

\section{Formative Experiences}

Despite the enormous, enduring influence of Wick Skinner's writing and ideas and the worldwide acclaim he has received during his lifetime, the memory of his disastrous first presentation at an academic seminar over 40 years ago still rankles in his mind. His critics on that cold December afternoon in 1960 did not argue much with his firsthand experience and observations; they simply disagreed with the conclusions he drew from them. Wick walked out of that experience bloodied but unbowed, and determined to see his views vindicated. He was not easily intimidated, even then. Although only in his third year of doctoral studies at the time, he was not your typical young faculty Lecturer.

By then it already had been over 16 years since he had graduated from Yale with a Chemical Engineering degree (achieved in a war-accelerated 33 months). Immediately inducted into the Army, he soon was assigned to the Engineering Corps working on the Manhattan Project at Las Alamos. Most histories of that project focus on the theoretical breakthroughs that underpinned the development of the atomic bomb and neglect the fact that actually making the first bombs required a huge and complex engineering/manufacturing effort. Wick spent much of his time measuring material and manpower flows, and he was fascinated by the valuable insights that could be gained through such analyses. That experience, among others, led him to enter the MBA program at the Harvard Business School (HBS) after the war. Upon graduation in 1948 he joined the Honeywell Corporation where he spent 10 years -6 of them in production, 2 in marketing, and 2 as a divisional finance officer, and where he received his on-the-job education as an operating manager. The perspectives provided by these various functional experiences not only provided the fodder for several of the cases he wrote during the next few years, but also enriched the way he looked at management problems the rest of his life.

An opportunity to lead some management development classes at Honeywell reawakened a love of teaching and a renewed admiration for the transforming experience that HBS had provided young people like himself. Its emphasis on the real life dilemmas that managers encountered, and how careful observation and analysis could help them understand and resolve these dilemmas, often in counterintuitive ways, had been deeply appealing to his practical, independent nature. He had emerged full of confidence in himself and even more convinced of the importance of testing theories and conventional wisdom against firsthand 
experience. A desire to have a similar impact on future students led him to pursue a teaching career at Harvard, figuring that he could always return to industry if academic life proved to be unsatisfying.

In the course of his doctoral studies, Wick spent 12 months writing cases, visiting 15 companies in a dozen industries, and writing a thesis on U.S. companies manufacturing abroad. What he saw going on in the companies he visited was reinforced by his business experience, and this profoundly disturbed him for two reasons. First, despite the apparent success of American industry, measured in financial terms, he saw direct evidence of deterioration and management failings down on the factory floor. Second, there seemed to be a complete mismatch between the problems the manufacturing managers of that period were facing and the research and teaching that he observed going on in academia. Neither the "old-fashioned" Industrial Engineering approaches, such as time and motion studies, Gantt Charts, job standards, quality sampling, and EOQs, or the new management science techniques based on mathematical modeling that were sweeping through academia seemed to have much relevance to the low morale and declining quality and productivity that he saw in companies, or to the lack of sufficient investment in new facilities and equipment at a time when imported products were rapidly increasing their market penetration.

Therefore, when he was asked to present some research findings to his new colleagues on the Production faculty at Harvard, Wick boldly asserted that in their pursuit of intellectual respect, most operations management academics had become so absorbed in developing, exploring, and attempting to apply new theories and techniques that they failed to see the difficulties that U.S. industry was experiencing as it confronted a changing-and much tougher-competitive environment. As a result, he felt that much of what academics were researching and teaching was not of great use to practicing managers, who found themselves being forced to "fight big battles with small weapons." Needless to say, this admonishment from the newest member of the faculty was not greatly appreciated, and Wick quickly developed a reputation as a rebel (he prefers the term "contrarian") —and, worse, a rebel against "progress." Moreover, although eloquent in his criticism of what academics and practitioners were doing wrong, either by omission or commission, he was unable to offer any persuasive recommendations for what they ought to be doing differently.

\section{U.S. Industrial Competitiveness}

Wick kept his contrarian ideas largely to himself over the next few years, devoting his energies to building a reputation as an extraordinary teacher and developer of teaching materials, converting his doctoral thesis into a book (Skinner 1968), and co-authoring several casebooks. Meanwhile he kept trying to figure out what was going wrong in U.S. industry (and why, in contrast, Japanese and German companies seemed to be "getting it right"), and what companies and academics ought to be doing about it. He explored these ideas in speeches to alumni and industry groups, attacking the conventional wisdom of the time by arguing that great marketing, elaborate control systems, and financial wizardry were not sufficient by themselves to enable a company to compete successfully against competitors that were really good at operations.

These ideas led eventually to a Harvard Business Review article "Production Under Pressure" (Skinner 1966). He began by asserting that U.S. industry, without much top management attention or understanding, was going through a process of “ . . replacing the techniques, skills, facilities, and even the managers of an already outmoded concept of production ... [called] 'mass production'." These fundamental changes were undermining the effectiveness of the conventional (i.e., Tayloristic) approach to solving manufacturing problems, which involved breaking them down into their parts, improving each part, and imposing standards to lock in the selected improvements. Companies needed to take a whole 
new approach to manufacturing, he argued. Top management was going to have to stop delegating and start getting personally involved, and this would probably require a new generation of manufacturing managers-people who could "perceive the production system as a whole, take a company rather than a departmental point of view" and bring to bear a whole new set of tools and specialists to the task. Finally, he admonished educators for failing to "communicate effectively ... that life in the factory is changing and that the needs and opportunities for creative and skilled production managers are going to increase dramatically in the next 20 years." This basic argument became the first major theme in his work.

Almost 20 years later, he returned to his argument in "The Taming of Lions: How Manufacturing Leadership Evolved 1780-1984" (Skinner 1985) with a perspective enriched by both his study of history and his experiences during the intervening years (including, as will be seen, developing and teaching courses in Human Resource Management). In this paper he asserted that the management problems of the 1980s were "due to a 'mind set' of mistaken premises and implicit objectives which are rooted in the history of production management, and are now inappropriate and dysfunctional." After summarizing this history and its implications, he asked "whether the harsh environment of the last 20 plus years is bringing about a new generation of manufacturing managers who will cope better." Interviews with 60 young managers from six different manufacturing companies suggested an encouraging answer, because they seemed to "have a broader view... [and were] more outspoken, more zealous, more participative ... team builders, ... and more strategically oriented."

\section{Manufacturing Architecture, Infrastructure, Task, and Focus}

During the 1960s, he also was asked to teach an elective course called Advanced Production Problems (APP). Rather than proceeding from one category of problems to another, as in most courses, this course took an "industry approach": focusing on the market environment, economics, process technologies, and manufacturing management problems in a single industry for 9-12 class sessions before moving onto a different industry. Students observed that even within the same industry different companies adopted different approaches to competition, and these different approaches inevitably required different policies regarding such manufacturing issues as the location of facilities, production controls, make versus buy, and administrative structures. Any attempt to apply a uniform "one best way" (e.g., mass production) approach to such issues usually led to conflicts between strategy and policies. This became the second recurring theme in Wick's work. The APP course was extraordinarily popular when taught by him; it received the highest student ratings and was always overregistered even though students also rated the course as having the heaviest workload. Several well-known consulting firms and investment banks were reported to have strongly suggested to potential recruits that they considered APP to be a "required" course.

Another formative experience during this period was teaching a course that focused on the new production technologies, both hardware and software (what today would be called AMTs) that were then being introduced. These included, for example, $\mathrm{NC}$ machine tools, computerlinked factory-data systems, MRP-I, and simulation. The problem with these AMTs, he discovered through extensive fieldwork, was that despite their promise, they seldom met companies' expectations. Was the solution to "fire the manager," as his students often proposed? In some cases that was probably justified, but digging further he and they came to realize that the introduction of any new technique or technology usually required concomitant changes in other parts of the production system-process specifications, maintenance practices, pay systems, supervision, etc. Any of these parts that conflicted with the AMT could bring it down. The lesson: a factory's infrastructure of people, systems, and policies was at least as important as the technologies employed, and it had to be adjusted to fit and support the introduction of anything new. 
This became a third recurring theme in his work. It was elaborated in a teaching note "The Stubborn Infrastructure of the Factory" and a book chapter "The Factory of the Future: Always in the Future?" (Skinner 1980), and was central to the conceptual framework he introduced in "Manufacturing-Missing Link in Corporate Strategy" (Skinner 1969). Wick developed that framework in 1968, the year after he was awarded tenure at HBS, while preparing to teach the final class of an executive program course. Throughout that course he had exposed his students to the puzzling problems and paradoxes then facing a number of American manufacturing managers-problems for which he himself did not have good answers. But at some point the insulation provided by Harvard's "non-directive" approach to teaching had to be removed, and Wick felt he needed to offer his students some sort of satisfying conclusion. How could experienced, successful managers go wrong by applying approaches to industrial management that had been tested, proven, and improved for over a century? Could efforts to improve productivity by doggedly seeking to reduce excess labor (both direct and indirect), inventories, and floor space, and pursuing economies of scale by consolidating several small factories into one, be misguided?

Indeed, his experience with many companies convinced him that they often were misguided and this led to plants whose structures and infrastructures were in disarray. Each of their elements was designed independently with a different objective, usually by "specialists," either internal or external, and each pulled in a different direction so that the manufacturing organization as a whole was not particularly good at anything. An "all-purpose" plant that tried to do everything, he had observed, was like an all-purpose tool in that it couldn't do anything as well as one designed and managed with a specific purpose in mind. Therefore, decisions that looked good from the point of view of consultants, accountants, and finance-driven managers often conflicted with a company's strategic mission. Manufacturing decisions were "right," not because they reflected conventional wisdom or maximized some financial criterion, but because they supported that mission.

The logical conclusion of this line of reasoning was that an effective manufacturing strategy consisted of a set of facilities and policies that were designed to maximize the organization's performance along the one or two most important performance measures that characterized the company's specific approach to competition. The responsibility of top management was to ensure that its manufacturing organization understood which criteria were most critical and verify that all its manufacturing policies were coherent, both with each other and with the company's competitive objectives. The class was a great success, and Wick finally felt he had something important to say to the world. He worked all summer on what was to become the "Missing Link" article, wherein he argued that "the variables of cost, time, quality ... and customer satisfaction ... demand an explicit recognition of a multitude of trade-offs and choices," and that "each [competitive] strategy creates a unique manufacturing task." The article appeared the following spring and spawned a whole new field of study, selling over 165,000 reprints and influencing three generations of academics.

Two years later his article "The Anachronistic Factory" (Skinner 1971) summarized and integrated the arguments in both "Missing Link" and "Production Under Pressure." In it he argued "a new engine does not make an old automobile new. Any one part . . . can render [the vehicle's performance] inadequate... the new engine may in fact bring out new problems which make total performance worse than before ..." He concluded that "The U.S. factory system is anachronistic on two counts:

1. Its management concepts are outdated, focusing on cost and efficiency instead of strategy, and on making piecemeal changes instead of changes that span and link the entire system.

2. Its infrastructure contains such conflict... that the ... desires of its people are too often incongruent with the imperatives of its technology, the demands of its markets, and the strategies of its managers."

Looking back, Wick recalled, "I respected the tools and techniques of industrial manage- 
ment that I had been taught, but they seemed like implements of 'housekeeping'. I came to see that all the 'housekeeping' in the world could not make a plant competitive if its architectural design was wrong. My interest was architecture."

Although the importance and usefulness of the themes of the "Missing Link" and "Anachronistic Factory" articles were quickly recognized in industry, and Wick soon became a sought after consultant and speaker, they were surprisingly slow to have an impact in academia. "My senior colleagues had received their doctoral training in the old mantras of operations management," he remembered, "and once mastered they found it very difficult to abandon that training. A good doctoral program is a powerful formative experience. Once you get very good at something, you continue to find it interesting and worthy of further study. The longer you study and teach it, the harder it gets to adopt a new way of thinking that demands entirely different premises and skills." So he began the long process of building a support group by involving several junior faculty members-among them Robert Hayes, Earl Sasser, Roger Schmenner, and Steven Wheelwright-in some of his consulting and teaching projects.

Two of these projects were particularly rewarding because they stimulated him to extend his manufacturing strategy framework and led to astonishing improvements in the companies that adopted his proposals. The first company was trying to service five quite different businesses out of a single all-purpose plant. Wick suggested that each business should be separated organizationally, develop an approach to manufacturing that was appropriate for its particular situation, and be assigned its own dedicated manufacturing facility. The results were immediate and significant and thus was born the notion of a "focused factory."

In that seminal article (Skinner 1974), which also sold well over 100,000 reprints, Wick reprised his argument that different competitive strategies require different operations structures. Just as a company must choose, train, and manage a sales force differently if its primary task is to sell expensive pieces of capital equipment to experienced engineers as opposed to selling inexpensive consumer disposables to unsophisticated buyers, it needs different types of operations organizations for different missions. It was not, of course, impossible for the same operations organization to produce/deliver two different kinds of products/services that compete for customers in very two different ways; indeed, many companies operate this way. However, Skinner argued, one cannot expect that organization to perform both tasks equally well, or as well as could two different organizations that each focused its attention on a single task.

Therefore, even if it were equipped with the most modern equipment and systems, he asserted, a single facility that attempted to pursue several markets employing different competitive strategies would inevitably experience both irreconcilable conflicts and a loss of overall effectiveness. An "all-purpose" facility, he proposed, could only become a competitive asset if it were broken up into two or more focused facilities, for each of which the "entire apparatus is focused to accomplish the particular manufacturing task demanded by [its specific] strategy ..." This notion, with its emphasis on simplicity, clarity, and low overhead, foreshadowed the more modern concept of "lean manufacturing."

The second project gave Wick an opportunity to test this idea in a different environment, and it became one his most publicized successes. The Copeland Corporation produced a variety of refrigeration and air conditioning compressors out of a single large plant in Ohio. With Wick's guidance, the company's CEO decided to "bet the company" by investing all its available capital into building a new, focused factory for the company's major product line. The success of this facility led Copeland to construct focused facilities for two other major product lines. Within 5 years the competitive advantages provided by this set of focused factories had forced two big competitors to drop out of the business, and Copeland's worldwide market share rose from $15 \%$ to $60 \%$. (Additional information is contained in the case series "Copeland Corporation: Evolution of a Manufacturing Strategy, 1975-1982.")

The same two themes, underscored and informed by the competitive problems confronting 
U.S. industry during the 1980s, were reprised in "The Productivity Paradox" (Skinner 1986). However, whereas the managers of the 1960s were largely unreceptive to his arguments, by the mid-1980s they no longer could deny that they were face to face with a competitive crisis. He warned them that "resolutely chipping away at waste and inefficiency-the heart of most productivity programs - is not enough . . . to restore competitive vitality ... These programs ... have the wrong targets and misconstrue the nature of the competitive challenge they are supposed to address.... [A] focus on cost reductions ... absorbs managers' minds and diverts them from more effective... approaches." These more effective approaches, he asserted, included pursuing ways other than low cost to achieve a competitive advantage, adopting new process technologies, and making "major changes in the selection, development, assignments, and reward systems for manufacturing managers." The article won the McKinsey Award for best article published in the Harvard Business Review that year.

In 1978 Wick authored Manufacturing in the Corporate Strategy (Skinner 1978), a book that summarized much of his work during the previous decade. Its publication, in a sense, represented a watershed in his intellectual direction. Until then he had focused his attention primarily on strategy - on the "architecture" of companies, to use his word. By now, however, he had become increasingly baffled by the inability of many managers to be successful even within a supportive architecture. The problem, he felt, lay not just at the level of strategy but another level down in the corporate pyramid, with the people he called "operating managers." He had become increasingly appreciative of the impact-for good or ill-that a single manager could have on an organization, and he was trying to understand the characteristics and behaviors that caused some operating managers to be effective or ineffective.

\section{The Operating Manager, Working Through People}

As a consultant, he often had been frustrated by the inability of managers who were trained in (and often had years of success implementing) the mass production paradigm to recognize the changes taking place in industry and adopt new ways of thinking and managing. As the chairman of the POM faculty at HBS, he was similarly frustrated by the difficulty of getting academics to do the same, as well as by his students' increasing fascination with the mindset and tools of consultants (which tended to be confined to detached analysis at a strategic level) as opposed to those of the practicing manager. Treating manufacturing as part of the corporate strategy was a necessary, but not a sufficient condition for corporate success. Putting the strategy to work was the tough part. Managers' day-to-day actions were at least as important as the strategic plan they operated under. This final recurring theme in his teaching and writing, rooted in his early experiences at Honeywell and reinforced throughout his academic career, received increasing emphasis as time passed.

Building on his experience recruiting and mentoring a "new breed" of young POM professors at HBS, he focused his attention on how companies should go about selecting, developing, and grooming good managers. He began in 1976 by developing a new elective course titled "The Operating Manager" that focused on the nuts and bolts of line management. It soon became so popular that he enlisted Earl Sasser to help him teach it; later Steve Wheelwright joined the team. That experience demonstrated to Sasser that "Wick really knew what it took to make things happen on the manufacturing floor."

Out of that course came the article "Managers with Impact: Versatile and Inconsistent" (Skinner and Sasser 1977), which began by asking, "Why do so many managers who appear crisp, logical, and determined at the conference table frequently accomplish little or nothing when they return to their offices? But why do other managers work effectively both within and outside their organizations and produce a string of significant accomplishments in a short time?" Based on their research several answers were suggested, most surprisingly that effective managers tended to be inconsistent in a certain way. Earl Sasser recalls that "the 
word 'inconsistent' was so unlike Wick." After all, he was the manufacturing strategy "guru" who always preached the importance of maintaining consistency over time between a company's strategy and its manufacturing architecture and infrastructure. "At the operating level, however, situations and problems changed so quickly that a manager continually had to size up the operating task and perhaps utilize a different (even inconsistent) managerial tool to deal with it. The more tools one mastered, the more versatile the manager." Conversely, they argued, for less effective managers "Consistency is their downfall ... a tendency to persist in using a limited number of tools and techniques, based on a small assortment of managerial premises which they use over and over again."

Worrying that students would associate such concerns only with managers in the manufacturing function, he left that course in the capable hands of Sasser and Wheelwright and developed another new elective entitled "The Manager and Personnel." There he explored with his students the critical role that human resource development played in organizational success. The success of these two experiences led him to propose that the School develop and offer a new required course on Human Resource Management, which he undertook with the collaboration of members of the School's Organizational Behavior faculty, including Paul Lawrence and Richard Walton. Out of those experiences came a number of cases and notes, and "Big Hat, No Cattle: Managing Human Resources" (Skinner 1981), an article that decried the lack of real imagination or effectiveness of the kind of human resource management he saw being practiced in too many American companies. "Human resources management seems to be mostly good intentions and whistling in the dark," he asserted, and then went on to describe the reasons for its ineffectiveness and what should be done differently.

\section{The "Bottom Line"}

After teaching that course for a couple of years, and after much thought (but no second thoughts!), Wick decided to take early retirement from Harvard in 1986, at age 60. "I love this institution and the teaching and writing that I'm doing here, but there's just too many other things I want to do," he confided to one of his friends. "I hope to stay current with what's going on in academia and continue to teach and write, but I also want to spend more time traveling, developing my other interests, and giving back to some of the institutions and causes that I feel to be important."

Despite the prognosis from that disastrous first seminar presentation, Wick's illustrious academic career has been showered with honors. The author or co-author of over 75 articles and book chapters, as well as 10 books, his Harvard Business Review articles alone have sold over half a million reprints. His abilities and leadership qualities have been recognized not only at Harvard, where he held numerous high administrative positions (including Chair of the MBA program) and was given its Distinguished Service Award in 1996, and in the POM community, but in the larger academic community as well. He was elected a Fellow of the Academy of Management in 1976 and recently was awarded an honorary doctorate by the University of Ghent.

In addition to these academic honors, Wick has served on the Boards of over a dozen organizations, both profit and non-profit. These include four institutions of higher learning (he currently is a member of the Board of Trustees of the University of Maine system) and two environmental groups (including 3 years as the president of the Natural Resources Council of Maine), as well as the Farnsworth Museum in Rockland, Maine (currently its president) and the Maine Public Broadcasting Corporation (currently its vice-chairman).

For the past 15 years he and his wife Alice have lived year round on the coast of Maine, where they had maintained summer homes for a number of years. He learned to fly his own plane and, having expanded his fleet of boats to nine (their flagship being his 40-foot sailing cruiser Calliope, named after one of the nine Muses in Greek mythology), he now responds to the title "Admiral" as readily as "Professor." When not occupied with one of his many 
professional activities, he is either out on the water, playing tennis, swimming, applying paint to canvas, or entertaining legions of guests.

As he had promised himself, all these distractions have not slowed his academic activities. He has run seminars and been a visiting scholar or lecturer at half a dozen institutions, served as president of both the Operations Management Association and the Production and Operations Management Society, and published over 20 articles. These include three pieces (Skinner 1996a-c) in the widely cited spring 1996 Special Issue on Manufacturing Strategy of Production and Operations Management, which he edited. All this since he retired from the Harvard faculty. Would that we all could be so productive during our retirements!

\section{References}

SkInNER, W. (1966). "Production Under Pressure," Harvard Business Review, November-December, 139-146. (1968). American Industries in Developing Economies, John Wiley \& Sons, New York.

(1969). "Manufacturing-Missing Link in Corporate Strategy," Harvard Business Review, May-June, $136-145$.

(1971). "The Anachronistic Factory," Harvard Business Review, January-February, 61-70.

(1974). "The Focused Factory," Harvard Business Review, May-June, 113-121.

(1978). Manufacturing in the Corporate Strategy, John Wiley \& Sons, New York.

(1980). "The Factory of the Future: Always in the Future?" in Towards the Factory of the Future, L. Kops (ed.), American Society of Mechanical Engineers, Chicago, IL.

(1981). "Big Hat, No Cattle: Managing Human Resources," Harvard Business Review, September-October, $106-114$.

(1985). "The Taming of Lions: How Manufacturing Leadership Evolved 1780-1984" in The Uneasy Alliance: Managing the Productivity-Technology Dilemma, K. Clark, R. Hayes, and C. Lorenz (eds.), Harvard Business School Press, Boston, MA, 63-110.

(1986). "The Productivity Paradox," Harvard Business Review, July-August, 55-59.

(1996a). "Introduction to the Special Issue on Manufacturing Strategy," Production and Operations Management, 5, 1, 1-2.

(1996b). "Manufacturing Strategy on the 'S' Curve," Production and Operations Management, 5, 1, 3-14. (1996c). "Three Yards and a Cloud of Dust: Industrial Management at Century End," Production and Operations Management, 5, 1, 15-24.

AND W. E. SASSER (1977). "Managers with Impact: Versatile and Inconsistent," Harvard Business Review, November-December, $140-148$.

Robert H. Hayes is the Philip Caldwell Professor, Emeritus, at the Harvard Business School. Prior to his appointment to the Harvard Faculty in 1966, he worked for I.B.M. and McKinsey \& Company. He received his B.A. from Wesleyan University, and his M.S. and Ph.D. degrees from Stanford University.

His current research is concerned with manufacturing competitiveness, technological development, and the integration of design with manufacturing. He has published widely; three of his articles won McKinsey Awards for the best articles published in the Harvard Business Review during various years. Recent articles include "Operations-Based Strategy," co-authored with David Upton (California Management Review, Summer 1998) and "Beyond World-Class: The New Manufacturing Strategy," co-authored with Gary Pisano (Harvard Business Review, Jan.-Feb. 1994). The book Restoring our Competitive Edge: Competing Through Manufacturing, co-authored with Steven Wheelwright, won the Association of American Publishers' Award for the best book on business, management, and economics published in 1984. The Uneasy Alliance: Managing the Productivity-Technology Dilemma (co-edited with Kim Clark and Christopher Lorenz) was published in 1985, and Dynamic Manufacturing: Creating the Learning Organization (co-authored with Steven Wheelwright and Kim Clark) in 1988. His latest book, Strategic Operations: Competing Through Capabilities (co-authored with Gary Pisano and David Upton), was published in early 1996.

Professor Hayes also has held a number of administrative positions at the School, including Area Head, Program Head, and Senior Associate Dean for Faculty Planning and Development. He was the Faculty Chairman for Harvard's International Senior Managers' Program in Switzerland for two years, where he studied and worked with a number of European companies. After living and conducting research in Asia for several months, in 1998 he coordinated the opening of HBS's new research office in Hong Kong. He is the President of the Production and Operations Management Society, and serves on the Boards of Directors of the American Productivity \& Quality Center, Helix Technology, Inc., and Applera Corp. He has been selected for listing in Who's Who in America. 